\title{
Mental Condition and Ventricular Size in Arrested Hydrocephalus: an Analysis of 29 Shunt-independent Children
}

\author{
G. J. HOLTZER, S. A. de LANGE, I. J. C. ORBAAN, R. GELSEMA
}

\section{Introduction}

It has been suggested that arrest of hydrocephalus results from enlargement of the ventricular surface (Foltz and Shurtleff 1963, Foltz 1965, Ransohoff 1965). Foltz (1965) has stated that a condition of shunt-independence is only achieved at a sacrifice of intellectual capacity due to enlarged ventricles. It seemed worthwhile, therefore, to measure the size of the ventricles in children who had become shunt-independent, and to compare these findings with earlier measurements. Psychological investigations were also performed so that the data obtained from these could be compared with those obtained from the ventricular measurements.

\section{Material}

Between 1959 and 1970, 202 infants with progressive hydrocephalus were admitted to the neurosurgical department of the Academic Hospital, Rotterdam (Table I). Children admitted with hydrocephalus caused by a tumour are not included in this total. Of these 202 infants, 180 were treated with a ventriculo-cardiac shunt (Holter valve), while treatment was with held in the other 22 because of a poor prognosis. 127 children are still alive, of whom 29 are known to be no longer shunt-dependent and have consequently had the drainage system removed (Table I). The hydrocephalus of these children has remained arrested. The period of follow-up after removal of the drainage system has ranged from 2 to $9 \frac{1}{2}$ years.

\section{Methods}

\section{Measurement of the Diameter of the Ventricular System}

The size of the ventricular system was measured by two-dimensional echoencephalography (B-scan). The contact compound scan technique was used, as developed in our neurophysiclogical department by Dr. M. de Vlieger (Denir van der Gon et al. 1966, de Vlieger et al. 1968). In this way, tomographic cross-sections of the ventricular system were obtained and the ventricular diameter was then calculated.

\section{Psychological Investigation}

Psychological assessment of the 18 children who were aged 5 years and older was carried out using the Wechsler Intelligence Scale for Children, the Terman test or the Stanford test. The remaining 11 children, who were less than 5 years old, were investigated, where possible, using the Sceno test. In addition, the Vineland Scale was applied, and as many other data as possible were collected. By using all these data, developmental assessment as well as an IQ estimation was made.

Neurosurgical Department, Academic Hospital, Rotterdam. 


\section{Results and Discussion}

\section{Ventricular Measurements}

The diameter of the ventricular system was successfully measured in 26 children (Table II); in the other 3 children the pictures of the B-scan did not allow a clear interpretation.

In 13 of the 26 cases, it was possible to compare the B-scan with a similar investigation performed 1-2 years previously at the time of removal of the drainage system. In 11 of these cases the diameter of the cella media appeared to be unaltered; in the other 2 cases the ventricles had decreased to a normal size.

\section{Psychological Investigation}

The IQ distribution in this series of 29 patients is shown in Table III.

TABLE I

Patients with progressive hydrocephalus treated between 1959 and 1970

\begin{tabular}{|c|c|c|c|}
\hline Aetiology & Total & Alive on 1.1.71 & Shunt-free \\
\hline $\begin{array}{l}\text { Congenital } \\
\text { with encephalocele, meningocele or } \\
\text { myelomeningocele } \\
\text { without lesions } \\
\text { Acquired (non-tumoral) } \\
\text { (meningitis, haemorrhage, etc.) }\end{array}$ & $\begin{array}{r}111 \\
60 \\
31\end{array}$ & $\begin{array}{l}59 \\
46 \\
\\
22\end{array}$ & $\begin{array}{r}13 \\
12 \\
4\end{array}$ \\
\hline Totals & 202 & 127 & 29 \\
\hline
\end{tabular}

TABLE II

Diameter of ventricular system in 29 children with arrested hydrocephalus

\begin{tabular}{|l|c|}
\hline $\begin{array}{c}\text { Diameter of the cella media } \\
\text { of the lateral ventricle }\end{array}$ & $\begin{array}{c}\text { No. of } \\
\text { patients }\end{array}$ \\
\hline Normal $(2 \cdot 0 \mathrm{~cm}$ or smaller $)$ & 6 \\
Slightly enlarged $(2 \cdot 0-2 \cdot 5 \mathrm{~cm})$ & 8 \\
Enlarged $(2 \cdot 5-3 \cdot 0 \mathrm{~cm})$ & 6 \\
Greatly enlarged $(3 \cdot 0 \mathrm{~cm}$ or more $)$ & 6 \\
No estimation possible & 3 \\
\hline
\end{tabular}

TABLE III

Distribution of IQ in 29 children with arrested hydrocephalus

\begin{tabular}{|c|c|c|c|}
\hline$I Q$ & $\begin{array}{c}\text { Investigated } \\
\text { patients } \text { (those } \\
\text { over 5 years old })\end{array}$ & $\begin{array}{c}\text { Estimated } \\
\text { patients } \text { (those } \\
\text { under 5 years old })\end{array}$ & Total \\
\hline $110-119$ & 1 & - & 1 \\
$100-109$ & 3 & 1 & 4 \\
$90-99$ & 7 & 4 & 11 \\
$80-89$ & 4 & 1 & 5 \\
$70-79$ & - & 3 & 1 \\
$30-69$ & 3 & 1 & 6 \\
30 and lower & - & 11 & 29 \\
\hline TOTALs & 18 & 1 & 1 \\
\hline
\end{tabular}




\section{Educational Activities}

Of the group of 18 children over 5 years old, 10 are in normal primary schools. They are achieving good results and show normal adaptation. A further two children (IQ 85 and 86 ) are attending a school for the physically handicapped, three (1Q 87, 90 and 94) are at a school for children with behavioural problems and the remaining three (IQ 53, 53 and 65) are in schools for the mentally retarded.

Of the 11 children under 5 years of age, 6 are expected to receive a normal primary-school education. Of these, 5 show a normal development and are well adjusted at infant school and at home; the sixth seems to be a little retarded at present, although he is improving and is expected to be able to attend a normal school. Of the other 5 children in this age-group, one will probably attend a school for the mentally retarded. Two others may do the same, but their educational prospects are less certain because they are also severely handicapped by the neurological sequelae of a lumbo-sacral myelomeningocele. Two patients have been admitted to an institution.

\section{Relationship Between Ventricular Width and Intelligence (Fig. 1)}

In this series, the relationship between ventricular width and intelligence is similar to that generally found between intelligence and skull circumference. The majority of children with the lowest IQs were found in the group with the greatest ventricular width, and the majority of those with the highest IQS in the group with the smallest ventricles. However, in the children with normal IQS, a great range in ventricular diameter was found. An enlarged ventricular system seemed to be quite compatible with a normal intelligence (Yashon et al. 1965). The associated brain lesion and heriditary factors are likely to influence the development of intellectual capacities to a greater extent than the ventricular diameter.

\section{Conclusions}

It appears that, contrary to the views stated by Foltz and Shurtleff (1963), Foltz (1965) and

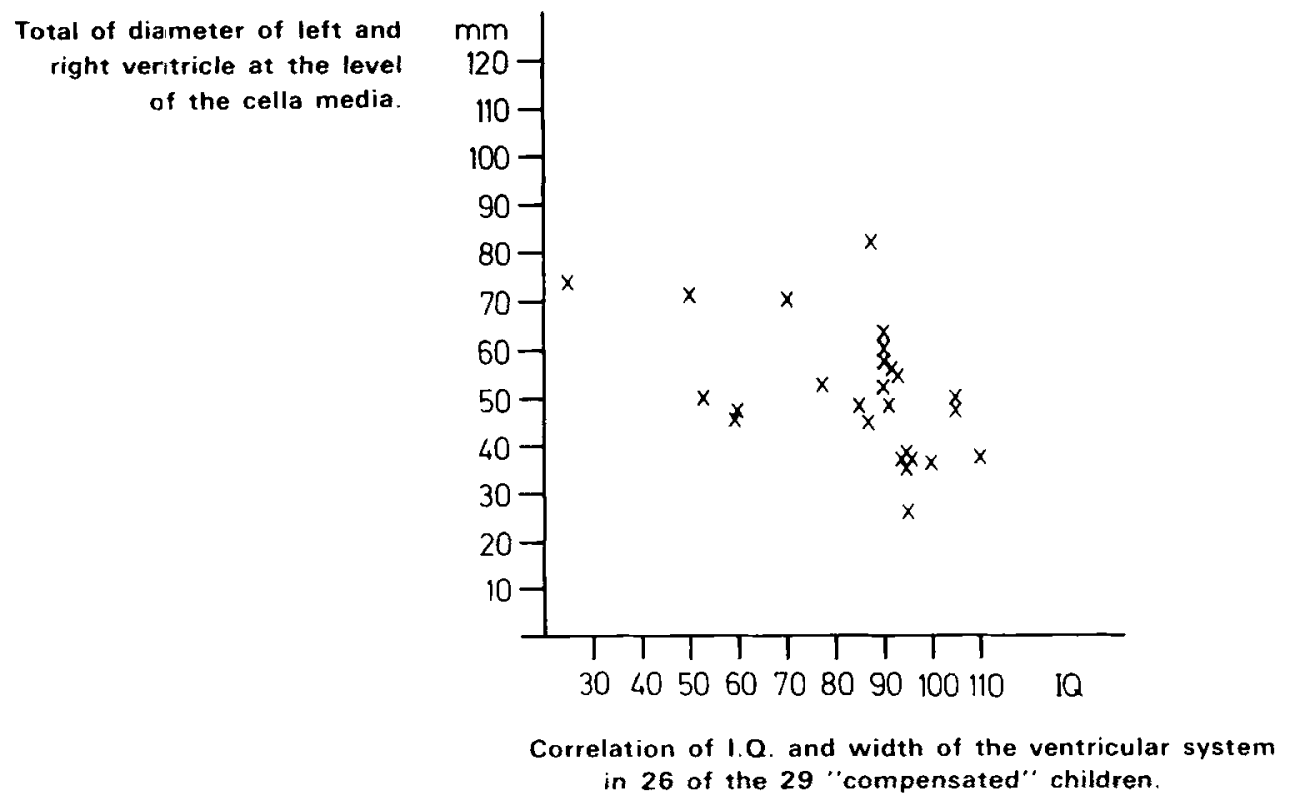


Ransohoff (1965), compensation or arrest of hydrocephalus after ventriculo-cardiac drainage can occur even when the ventricular surface is of normal size. Enlargement of the area of the ventricular ependyma can play a part in the arrest of hydrocephalus, but it is not always necessary.

There are other mechanisms which may play an important part in bringing about arrest of hydrocephalus. For instance, the theoretically possible factor of re-establishment of the CSF pathways has never been well evaluated in this condition. We did not undertake air studies in these children for fear of destroying the equilibrium between CSF production and absorption, but radioisotopic cisternography may prove to give useful additional data in the future. Other factors such as cerebral blood flow and biochemical-hydrodynamic processes may play a part, but are not as yet accessible for clinical investigation.

On the basis of our results, we feel that removal of a blocked shunt is justified when the child is in good condition, with normal cSF pressure and unaltered ventricular size.

In this series, removal of the drainage system did not result in an increase in the size of the ventricles: on the contrary, in two cases the ventricular size became normal. These indings and the data obtained from the psychological assessments make it plausible that the condition of shunt independence in these children has not been achieved at the expense of their intellectual capabilities.

Finally, we would like to point out how useful two-dimensional encephalography has proved to be in the investigation of patients with hydrocephalus. It is extremely suitable for out-patient clinic follow-up examinations because its application is both easy and harmless.

\section{SUMMARY}

Measurement of the diameter of the ventricular system, in a series of 29 patients with arrested hydrocephalus who had become shunt-independent, showed that enlargement of the ventricles does not necessarily play a part in the arrest of hydrocephalus, for in many of these cases the ventricles were normal or only slightly enlarged.

A study was made of the relationship between ventricular width and intelligence. Although children with the lowest IQs usually had a very wide ventricular system and those with the highest IQs a ventricular system of normal size, normal intelligence was compatible with ventricles of any size. It is concluded from these findings, and from the fact that removal of the drainage system did not appear to increase the size of the ventricles, that shunt independence in these children did not result in diminished intelligence.

\section{RÉSUMÉ}

\section{Etat mental et dimension ventriculaire dans les hydrocéphalies stabilisées}

La mesure du diamètre du système ventriculaire chez 29 sujets avec hydrocéphalie stabilisée, devenus autonomes de shunts, a montré que l'élargissement des ventricules ne joue pas nécessairement un rôle dans l'évolution de l'hydrocéphalie, car dans de nombreux cas les ventricules étaient normaux ou très légèrement élargis.

Une étude a été faite de la relation existant entre la dimension ventriculaire et l'intelligence. En général, les enfants avec les plus bas QI avaient un système ventriculaire très élargi tandis que celui-ci était de taille normale dans les cas de QI élevé; cependant, une intelligence correcte peut s'observer avec un système ventriculaire de n'importe quelle dimension. A partir de ces données et du fait que la suppression du drain décroit plus qu'elle n'accroit la taille des ventricules, les auteurs concluent que l'autonomie de shunt chez ces enfants ne risque pas de diminuer l'intelligence. 


\section{G. J. HOLTZER S. A. DE LANGE I. J. C. ORBAAN R. GELSEMA}

\section{ZUSAMMENFASSUNG}

Geistige Verfassung und Ventrikelgröße bei versperrtem Hydrocephalus

In einer Serie von 29 Patienten mit versperrtem Hydrocephalus, die vom Shunt unabhängig geworden waren, zeigte die Messung des Durchmessers im Ventrikelsystem, da 3 die Vergrößerung der Ventrikel nicht unbedingt bei der Versperrung des Hydrocephalus eine Rolle spielen muß, da in vielen Fällen die Ventrikel normal oder nur gering vergrößert waren.

Uber die Beziehung zwischen der Weite der Ventrikel und der Intelligenz wurde eine Studie durchgeführt. Obwohl die Kinder mit den niedrigsten IQs gewöhnlich ein sehr weites Ventrikelsystem haben, die mit den höchsten IQs ein Ventrikelsystem von normaler Größe, kann die Intelligenz doch bei allen Ventrikelgrößen festgestellt werden. Aus diesen Befunden und aus der Tatsache, daß die Entfernung des Drainagesystems die Ventrikel eher zu verengen als zu erweitern schien, wurde abgeleitet, da $B$ die Shunt-Unabhängigkeit bei diesen Kindern nicht eine Verringerung der Intelligenz bewirkte.

\section{RESUMEN}

\section{Estado mental y tamaño ventricular en la hidrocefalia detenida}

La medición del diámetro del sistema ventricular en una serie de 29 pacientes con hidrocefalia detenida y que se habían convertido en independientes del shunt, mostró que el aumento de volumen de los ventrículos no juega necesariamente una parte en la detención de la hidrocefalia, ya que en muchos de estos casos los ventrículos eran normales o sólo ligeramente aumentados.

Se estudió la relacion entre la anchura ventricular y la inteligencia. Aunque los niños con c.I. más bajo generalmente tenian un sistema ventricular muy grande y los de C.I. más alto poseian un sistema ventricular de tamaño normal, la inteligencia era compatible con cualquier tamaño ventricular. Se concluye de estos hallazgos y del hecho de que al eliminar el sistema de drenaje disminuía más bien que aumentaba el tamaño de los ventrículos, que la independencia del shunt en estos niños no daba lugar a una inteligencia disminuida.

\section{REFERENCES}

Denier van der Gon, J. J., Duinhouwer, J. C., Molin, C. E., de Vlieger, M. (1966) 'Equipment of two dimensional ECHO-encephalography.' Neurology (Minneap.), 16, 927.

de Vlieger, M., Denier van der Gon, J. J., Molin, C. E. (1968) 'Two dimensional ECHO-encephalography of the third ventricle in hydrocephalus.' Neurology (Minneap.), 18, 473.

Foltz, E. L. (1965) 'The first seven years of a hydrocephalus project.' in Workshop in Hydrocephalus. Philadelphia: Children's Hospital of Philadelphia. p. 79.

- Shurtleff, D. B. (1963) 'Five years co-operative study of hydrocephalus in children with and without operation (113 cases).' J. Neurosurg., 20, 1064.

Ransohoff, J. (1965) 'New vistas in the treatment of hydrocephalus.' in Workshop in Hydrocephalus. Philadelphia: Children's Hospital of Philadelphia. p. 135.

Yashon, D., Jane, J. A., Sugar, O. (1965) 'The course of severe untreated hydrocephalus. Prognostic significance of the cerebral mantle.' $J$. Neurosurg., 23, 509. 